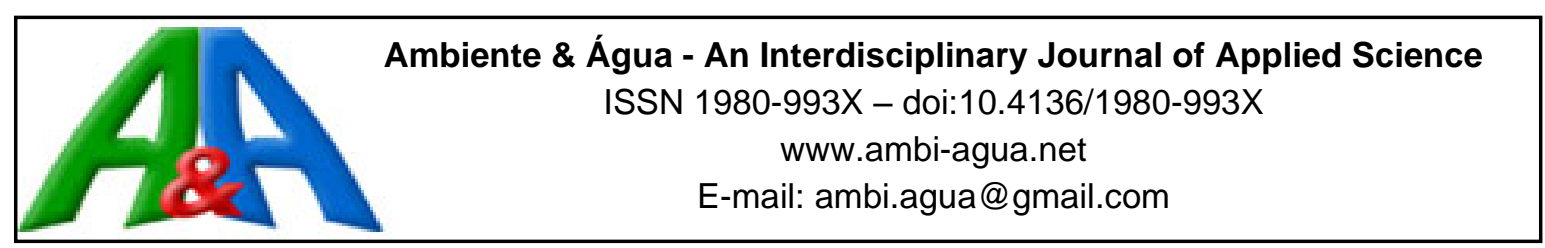

\title{
Efficiency of electroflocculation in the treatment of water contaminated by organic waste
}

\author{
ARTICLES doi:10.4136/ambi-agua.2484
}

Received: 08 Oct. 2019; Accepted: 26 Jan. 2020

\author{
Aline Nunes Andrade ${ }^{1(D)}$; Rodrigo Vieira Blasques ${ }^{1}$; Paulo Cesar Mendes Villis ${ }^{2}$; \\ Darlan Ferreira Silva ${ }^{2 *}$; Wolia Costa Gomes ${ }^{2}$ \\ ${ }^{1}$ Universidade Ceuma, Rua Josué Montello, n 1, CEP: 65075-120, São Luís, MA, Brazil. \\ E-mail: alinenunees@icloud.com, blasques@live.com \\ ${ }^{2}$ Programa de Pós-graduação em Ciências Ambientais. Mestrado em Meio Ambiente. \\ Universidade Ceuma, Rua Josué Montello, n 1, CEP: 65075-120, São Luís, MA, Brazil. \\ E-mail: paulovillis@yahoo.com.br,woliacg@gmail.com \\ *Corresponding author. E-mail: darlanveggito@hotmail.com
}

\begin{abstract}
Population growth has led to occupation and housing near rivers and lakes. This contributes to the increase of water pollution. The industrial laundry sector, for example, consumes a large quantity for its processes and pollutes water bodies due to the improper disposal of its effluents which contain numerous harmful compounds. This study employed electroflocculation in effluent treatment and evaluated its efficiency by analyzing turbidity, chemical oxygen demand, and $\mathrm{pH}$ levels. It used aluminum and zinc plates as sacrificial electrodes and principal component analysis (PCA) as a statistical tool. A maximum electroflocculation time of $40 \mathrm{~min}$ was utilized in order to obtain efficient results from the study. The experiment showed significant improvement in the water quality in the physicochemical aspects, primarily concerning the reduction of organic matter in the effluent. The efficiency of this treatment increased with higher current; however, both the aluminum and zinc plates reacted differently to $\mathrm{pH}, \mathrm{COD}$, and turbidity. Two principal components were generated to explain $86.90 \%$ of the data variance in the experiment. The principal component analysis indicated that the aluminum electrode showed the best correlation $(|>0.5|)$ for $\mathrm{pH}, \mathrm{COD}$, and turbidity in the effluent treatment.
\end{abstract}

Keywords: electroflocculation, principal component analysis, water treatment.

\section{Eficiência da eletrofloculação no tratamento de águas contaminadas por resíduos orgânicos}

\section{RESUMO}

O crescimento populacional levou a ocupações e habitações perto de rios e lagos. Isto contribui para o aumento da poluição da água. O setor de lavanderia industrial, por exemplo, consome alta quantidade de água para seus processos e polui os corpos d'água devido ao descarte inadequado de seus efluentes, que contém inúmeros compostos nocivos. Este estudo utiliza a eletrofloculação no tratamento de efluentes e avalia sua eficiência por meio da análise de turbidez, demanda química de oxigênio (DQO) e níveis de pH. Utilizou chapas de alumínio e zinco como eletrodos de sacrifício e análise de componentes principais (PCA) como 
ferramenta estatística. Foi utilizado um tempo máximo de eletrofloculação de 40 min para obter resultados eficientes do estudo. $\mathrm{O}$ experimento mostrou melhora significativa na qualidade da água nos aspectos físico-químicos, principalmente no que diz respeito à redução da matéria orgânica no efluente. A eficiência desse tratamento aumentou com o aumento da corrente, porém, tanto as placas de alumínio quanto as de zinco reagiram de forma diferente ao $\mathrm{pH}, \mathrm{DQO}$ e turbidez. Dois componentes principais foram gerados para explicar 86,90\% da variância dos dados no experimento. A análise dos componentes principais indicou que o eletrodo de alumínio apresentou a melhor correlação $(|>0,5|)$ para $\mathrm{pH}$, DQO e turbidez no tratamento de efluentes.

Palavras-chave: análise de componentes principais, eletrofloculação, tratamento de águas.

\section{INTRODUCTION}

Water scarcity is a universal problem that is a result of population growth and lack of adequate sanitation, where a high load of untreated organic, inorganic, and toxic materials is discharged, making this resource unfit for human consumption. The preservation of water resources is a global concern, as wastewater can be reused for water supply. This is practiced in all sectors, including irrigation, industrial, and urban areas (Behling et al., 2019).

Human activity, industrial or otherwise, generates waste. Dyes, greases, oils, and other byproducts cause various environmental problems, and major contaminations can be linked to oil refineries, chemical industries, textile, pharmaceuticals industries, sewage, agriculture and, household waste. As water scarcity increases, the world depends on developing new technologies for the treatment of toxic organic compounds (Aquino Neto et al., 2011).

According to Marques (2017), the lack of piped sewage, poorly constructed wells, and the absence of garbage collection are some of the main problems with basic sanitation in most Brazilian cities.

The National Water Resources Policy (NWRP), Law 9.433/1997 (Brasil, 1997), does not regulate effluents, although it ensures the availability of water, manages the rational and integrated use of water resources, creates quality standards for its uses and regulates prevention and defense against critical hydrological events. Article 9 of the NWRP classifies water bodies based on their principal uses and guarantees water quality. It aims to mitigate the costs of pollution control by adopting permanent preventive actions (Bandeira et al., 2018).

The greatest challenge of humanity today is providing clean water to the majority of the population on a global scale. There is growing global concern with environment conservation due to rapid population growth, water consumption and quality requirements in various sectors of society, such as industry, which generates highly toxic and non-biodegradable solid and liquid wastes that should be treated (Adams, 2018).

Many physical, chemical, and biological methods are used to treat industrial wastewater from laundries; one such method is electrochemical treatment. Proper selection and control of electrodes in the electrochemical system is critical to minimize losses and optimize energy consumption (Ilhan et al., 2008).

The electroflocculation technique is one of the simplest and most efficient electrochemical treatments adopted to purify various types of water and industrial effluents. This technique uses simple, easy-to-operate equipment that reduces the amount of sludge. A coagulant is generated by the electrolytic oxidation of a suitable anode, which conducts the material electrically at the appropriate $\mathrm{pH}$ to an insoluble metal hydroxide, which is capable of removing a wide range of pollutants (Candito et al., 2012).

Electroflocculation uses gas bubbles produced by water electrolysis to remove suspended particles. The process consists of a treatment tank with a cathode and an anode where small 
bubbles of hydrogen and oxygen gas are produced by applying an electric current. The electroflocculation process has several advantages over air flotation methods: the bubbles produced are smaller than 1-30 $\mu \mathrm{m}$ diameter, while those produced by scattered air flotation method are 50-100 $\mu \mathrm{m}$, thus having more surface area and a greater removal efficiency, particularly for finer particles $(10 \mu \mathrm{m})$ (Mohtashami and Shang, 2019; Kyzas and Matis, 2016).

For electroflocculation, the potential applied, the distance between the electrodes, the applied current, the temperature, and the $\mathrm{pH}$ are important parameters to be considered. During electroflocculation, oxidation and reduction reactions occur at the anode and cathode, respectively, when a potential is applied to the cell. The greater the distance between the electrodes, the greater the potential applied. (Silva and Silva Neto, 2010).

Silva (2005) stated that anodic and cathodic reactions occurred inside the reactor during electroflocculation, which dissociated the water molecules, releasing ions and gases (oxygen and hydrogen) fundamental to the process's dynamics. In water electrolysis, oxi-reduction reactions occur as follows Equations 1 and 2:

$$
\begin{aligned}
& (-) \text { Cathode: } 2 \mathrm{H} 2 \mathrm{O}(\mathrm{l})+2 \mathrm{e}^{-} \rightarrow \mathrm{H}_{2}(\mathrm{~g})+2 \mathrm{OH}^{-}(\mathrm{aq}) \mathrm{E}_{\mathrm{red}}=-0,83 \mathrm{~V} \\
& (+) \text { Anode: } 2 \mathrm{H}_{2} \mathrm{O}(\mathrm{l}) \rightarrow \mathrm{O}_{2}(\mathrm{~g})+4 \mathrm{H}^{+}(\mathrm{aq})+4 \mathrm{e}^{-} \mathrm{E}_{\text {oxi }}=-1,23 \mathrm{~V}
\end{aligned}
$$

The overall reaction is obtained by doubling the cathodic reduction reaction (Equation 1), and adding the anodic oxidation reaction (Equation 2) Equation 3:

$$
2 \mathrm{H}_{2} \mathrm{O}(\mathrm{l}) \rightarrow 2 \mathrm{H}_{2}(\mathrm{~g})+\mathrm{O}_{2}(\mathrm{~g})
$$

The electroflocculation technique is multifactorial, as it considers factors that may influence the process, such as the interaction between constituents of the effluent treated. Such interactions cause difficulty in study and interpretation of the process. Therefore, the use of multivariate statistical analysis is essential, as it provides a better view of each study, which in most cases are not well described by conventional mathematics. Principal component analysis (PCA) is an exploratory method that assists in the elaborating the general hypotheses based on collected data. This technique is capable of separating relevant information from redundant and random information. In PCA, sample grouping defines the structure of the data set through graphs of scores (samples) and loadings (variables), whose axes are the principal components (PCs) on which the data is projected. Considering that one PC is orthogonal to another, it is possible to examine the relationships between samples and variables through scores and loading plots; therefore, the analysis of the set allows us to estimate the influence of each variable in each sample (Ferreira et al., 1999; Haswell and Wamsley, 1998; Sena et al., 2000; Sousa et al., 2019).

Thus, a clean and low-cost methodology is essential for the current scenario. Electroflocculation appears as a competitive alternative in wastewater treatment to reduce the Chemical Oxygen Demand (COD). Electrochemical treatment destabilizes the effluent pollutant molecules through an electrical potential applied to the sacrificial electrodes (usually iron $(\mathrm{Fe})$ or aluminum $(\mathrm{Al})$, and consequently, the cations generated react with the colloids of the treated solution floating in the form of hydroxides (Strate, 2014). The present study evaluated the electrolysis duration in effluent treatment using the electroflocculation technique, comparing $\mathrm{Al}$ and $\mathrm{Zn}$ electrodes for parameters such as temperature, $\mathrm{pH}$, turbidity, and COD, despite their cost during the process.

\section{MATERIALS AND METHODS}

\subsection{Water Sampling and Characterization}

Water samples were obtained from the Jansen Lagoon in Maranhão state, Brazil. The 
experiments were carried out in a custom-built aquarium with a volume of $10200 \mathrm{~cm}^{3}$, with two taps to collect the effluent during the process.

The $\mathrm{pH}$ was measured by a digital $\mathrm{pH}$ meter (Micronal brand) and turbidity was analyzed by the nephelometric method using a bench turbidimeter. For the COD analysis, $5 \mathrm{~mL}$ of the sample was pipetted with $2.0 \mathrm{~mL}$ of the catalytic solution $\left(\mathrm{H}_{2} \mathrm{SO}_{4}\right)$ and $1.0 \mathrm{~mL}$ of the digesting solution $\left(\mathrm{K}_{2} \mathrm{Cr}_{2} \mathrm{O}_{7}\right)$ and was placed in a cuvette and then in a digester for two hours at $150^{\circ} \mathrm{C}$. Once removed, it was allowed to stand for $10 \mathrm{~min}$. After resting, the cuvette was shaken and the supernatants were removed and read at $620 \mathrm{~nm}$ on a spectrophotometer.

The samples were analyzed before, during and after the electroflocculation tests. The methodologies for physicochemical characterization, sample preservation, and effluent stabilization time for future analysis were based on the Standard Methods for Examination of Water \& Wastewater (APHA et al., 1995). Three experiments were performed to evaluate the effects on the physicochemical variables with varying distances between the electrodes.

\subsection{Electroflocculation process}

The electroflocculation tests were performed using a bench electrolytic reactor and working electrodes: aluminum (130 mm x $70 \mathrm{~mm}$ x $3 \mathrm{~mm}$ ) and zinc (130 mm x $70 \mathrm{~mm} \times 3 \mathrm{~mm})$ positioned above the reactor and connected to a direct current source (Instrutherm brand, Model FA 3030). Two electrodes of the same type were separated with respect to the diameter of a non-conductive material (PVC rings) by varying distances of $0.5 ; 1.0 ; 1.5 ; 2.0$; and $3 \mathrm{~cm}$. Figure 1 represents the materials used in the experiments.

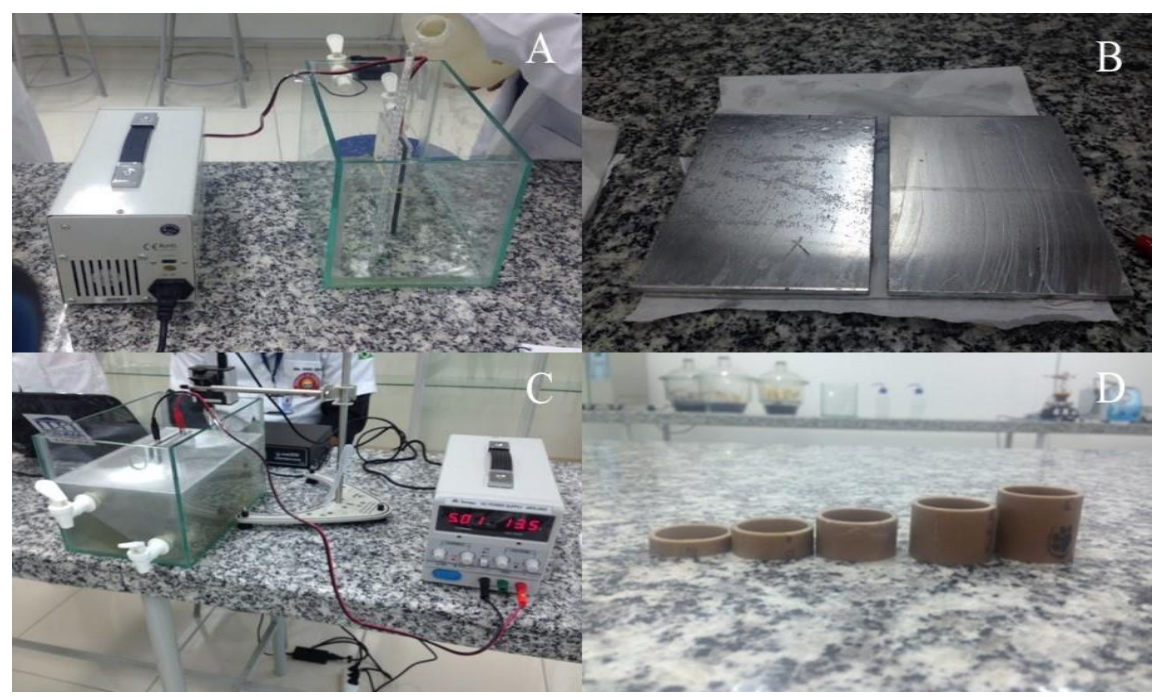

Figure 1. (A) Aquarium used; (B) Aluminum and zinc plates; (C) Bench reactor; (D) PVC rings.

Each electrode was tested for a reaction time of 5, 10, 20, 30, and 40 minutes to analyze if the electroflocculation filtered the water to eliminate the resident organic charge.

\subsection{Statistical analysis}

Statistical analyses were performed using Origin Pro 8 software. Principal Component Analysis (PCA) using Minitab 17 software correlated the variables and treatment time for aluminum and zinc electrodes.

The results of the physicochemical analysis displayed the mean and standard deviation $( \pm \mathrm{SD})$. Analysis of Variance (ANOVA) evaluated the differences between the distances of electrodes, the treatment duration, and the electrodes used in the experiment. A comparative test between the means was performed using the Tukey test $(\mathrm{p}<0.05)$. 


\section{RESULTS AND DISCUSSION}

The experimental electroflocculation setup for effluent treatment consisted of two aluminum electrodes or two zinc electrodes to evaluate the efficiency of each metal.

\subsection{Electroflocculation treatment}

\subsubsection{Effect of treatment time on effluent $\mathrm{pH}$ and temperature}

The results suggest that varying distances between the electrodes and the treatment time were the two factors that directly affected the process. For the aluminum electrode, a shorter distance between the electrodes $(0.5 \mathrm{~cm})$ with longer treatment time $(40 \mathrm{~min})$ contributed to an increase in the $\mathrm{pH}$ at the end of the process $(\approx 11.5)$ (Figure $2 \mathrm{~A})$. The responses of the zinc electrode treatment were contrary to the aluminum electrode as it resulted in a decrease in effluent $\mathrm{pH}(\approx 6.10)$ (Figure $2 \mathrm{~B})$. Kobya et al. (2003) report that changes in $\mathrm{pH}$ values vary according to the electrode material used. With the aluminum electrode (Figure 2A), the final $\mathrm{pH}$ is higher, caused by the formation of hydroxides due to the dissolution of electrodes while with the zinc electrode (Figure $2 \mathrm{~B}$ ); there is a reduction in $\mathrm{pH}$ as there is a decrease in dissolution. The $\mathrm{pH}$ tends to remain constant for both electrodes after 30 minutes of electrolysis, which is advantageous as the energy applied to the system decreases. Distance is another factor that directly influences the system's pH. According to Crespilho and Rezende (2004), the greater the distance between the electrodes, the greater the potential difference that must be applied, since the solution has resistance to the electric current flow. Thus, the characteristics of the effluent combined with the distance between the electrodes may be varied to improve the process's efficiency. The $2 \mathrm{~cm}$ distance for aluminum provided the best results, as it presented a lower $\mathrm{pH}$ range and lower electrode wear. For zinc, a distance of $1 \mathrm{~cm}$ was more advantageous for the $\mathrm{pH}$ range.
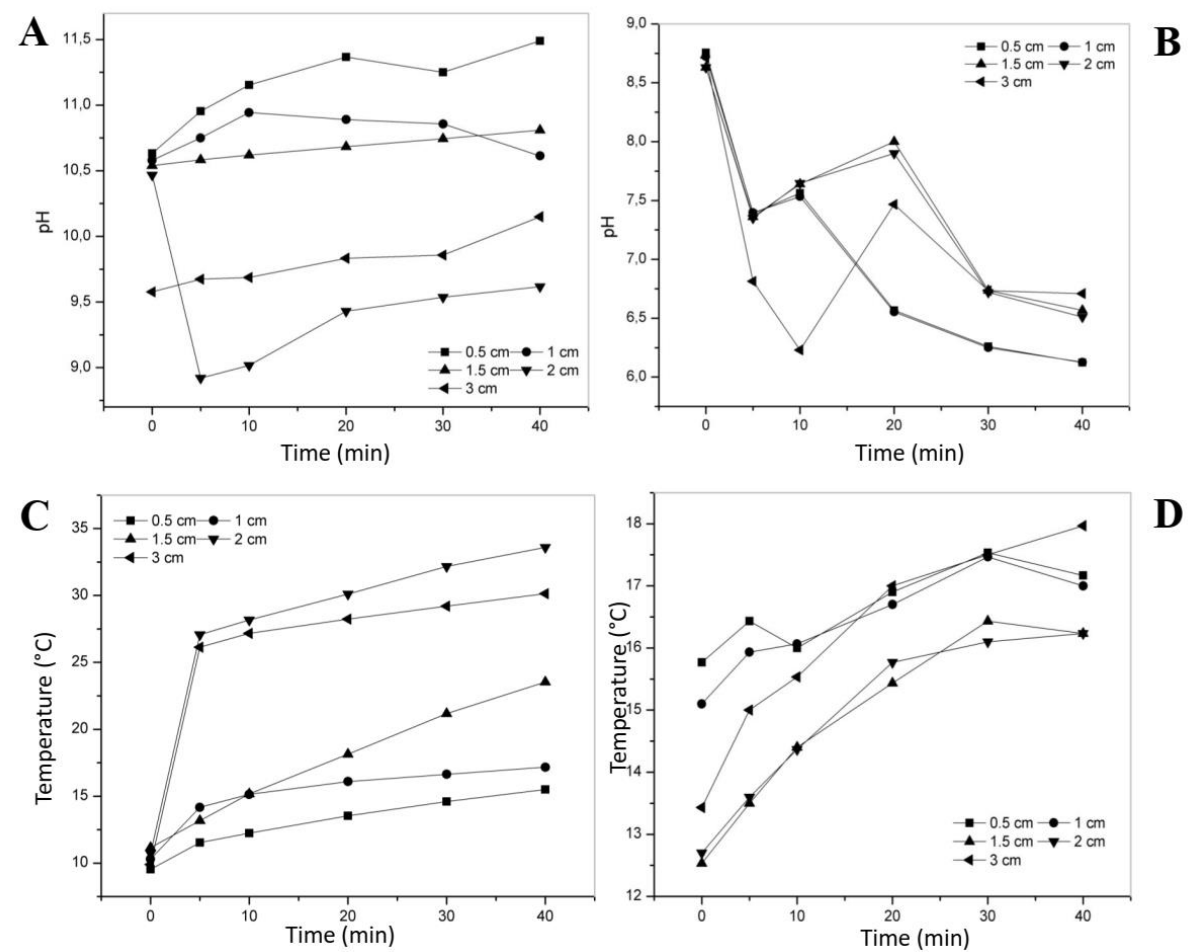

Figure 2. Experimental $\mathrm{pH}$ and temperature data in relation to the distances $(0.5,1,1.5,2$ and $3 \mathrm{~cm})$ between the electrodes during the electroflocculation process. A and C - using aluminum electrode; B and D - using zinc electrode. Applied potential: $5000 \mathrm{~mA}$. 
Aline Nunes Andrade et al.

Temperature has a direct influence on the electroflocculation process. Hydrogen gas microbubbles generated ascended rapidly to the foam layer and accumulated in the upper part of the effluent under treatment (Vieira and Cavalcanti, 2017; Abreu et al., 2019). This effect reduces the passivation of the electrodes and increases process efficiency. With both electrodes, the effluent temperature tended to increase during the process. Cerqueira (2006) states that efficiency can be maintained up to $60^{\circ} \mathrm{C}$ in the electrolysis process beyond which the efficiency decreases. With the aluminum electrode, the $2 \mathrm{~cm}$ distance between the electrodes caused the system temperature to reach approximately $33^{\circ} \mathrm{C}$ (Figure 2C). With the zinc electrode (Figure 2D), the maximum temperature reached was approximately $18^{\circ} \mathrm{C}$, for a $3 \mathrm{~cm}$ distance between the electrodes.

\subsubsection{Effect of treatment time on turbidity and COD}

Turbidity may be quantified by analyzing the intensity of light scattered by the sample, which relates the particulate materials to the transparency of the solution (Aquino Neto et al., 2011). The effluent turbidity analysis showed water transparency variations due to the suspension of organic and inorganic materials. Electrolysis increased the concentration of ions and their hydrogen flakes with time. The average turbidity value after 40 min of treatment for aluminum with electrodes $0.5 \mathrm{~cm}$ apart was approximately 98.7 to $38.6 \mathrm{NTU}$ (Figure 3A), while the zinc electrode showed no statistical difference (13.60 NTU) (Figure 3B).
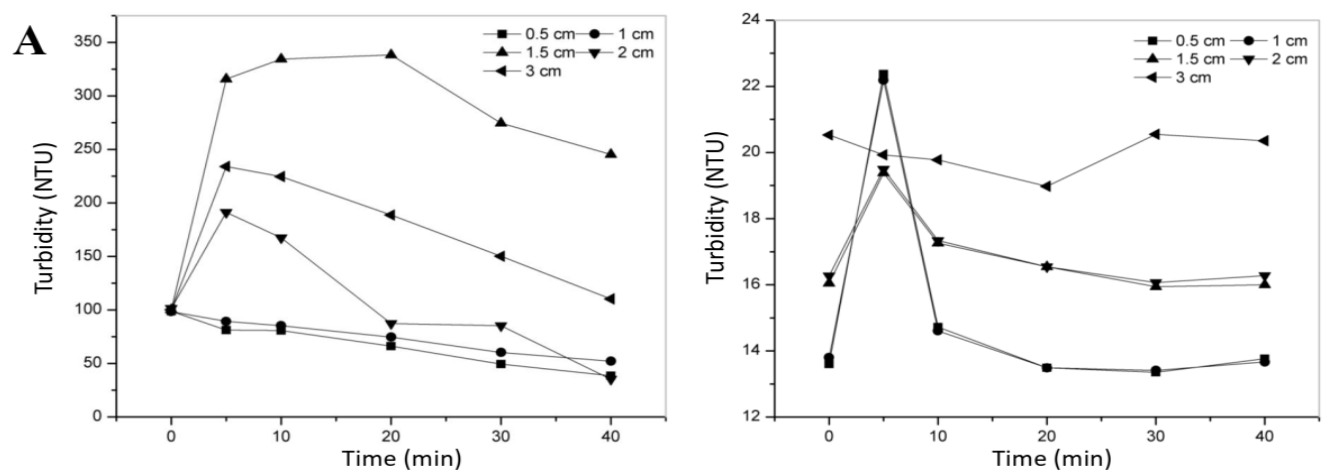

B
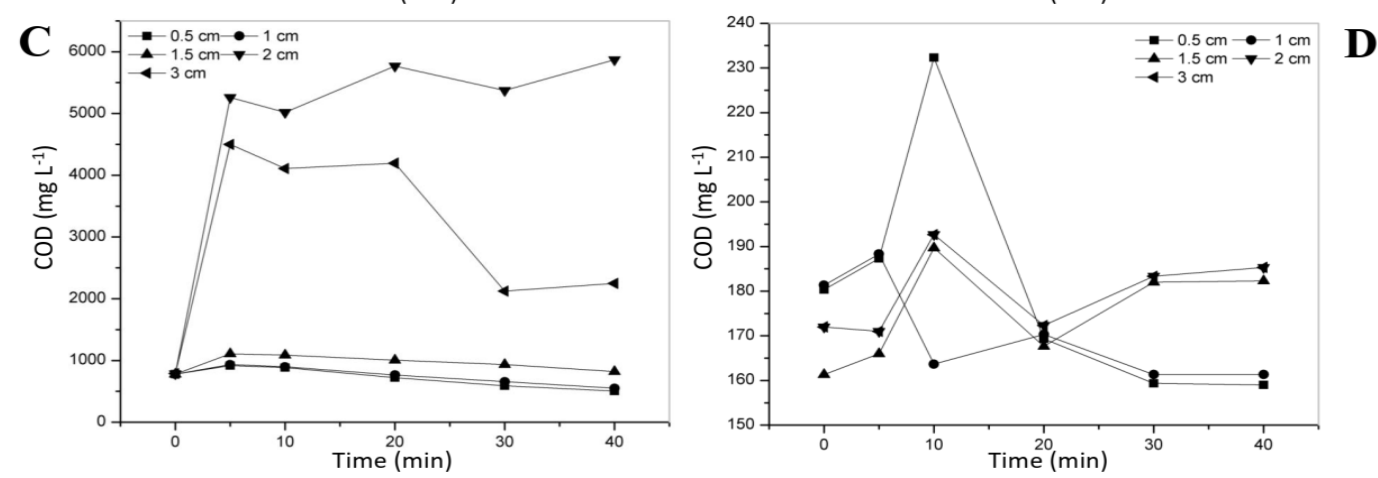

Figure 3. Experimental turbidity and COD data in relation to the distances $(0.5,1,1.5,2$ and $3 \mathrm{~cm}$ ) between the electrodes during the electroflocculation process. A and $\mathrm{C}-$ using an aluminum electrode; B and D - using a zinc electrode. Applied potential: 5000 mA.COD analysis studies the quality of dissolved oxygen. It is an important parameter in the characterization of polluted water (Bittencourt et al., 2018).

The oxygen demand presented a better response for the shortest distance between the electrodes $(0.5$ and $1 \mathrm{~cm})$, that is, a lower dissolved oxygen concentration produces the largest amount of reduced organic matter, thus increasing the efficiency of effluent treatment. The mean values ranged from 779.4 to $504.2 \mathrm{mg} \mathrm{L}^{-1}$ (Figure 3C) for treatment with the aluminum electrodes, and from 179.0 to $160.0 \mathrm{mg} \mathrm{L}^{-1}$ (Figure 3D) with the zinc electrodes. 


\subsection{Principal Component Analysis}

The multivariate analysis technique reduces a data matrix to fewer manageable variables, called principal components (PCs), where the first PCs contain the maximum variability (information) of the analyzed data set. The relationship between the samples and variables can be visualized and interpreted by a score and a loading plotting from the PCA (Karki et al., 2017; Higgins et al., 2019; Hajigholizadeh and Melesse, 2017).

The PCA was performed to evaluate the correlations between all the studied variables. From the results of PCA, principal component 1 (PC1) is most significant in describing the statistical model, explaining $57.70 \%$ of the total data variation using aluminum and zinc electrodes. The first two dimensions of the PCA explains $86.90 \%$ of the variance. Four clusters, three related to experiments performed with the aluminum electrode and one to the zinc electrode, were the highlights. The treatment using the aluminum electrode was the most efficient in terms of lower $\mathrm{pH}$, turbidity, COD, and temperature. Figure 4 shows the PCA for treatment duration and the parameters evaluated during the electroflocculation process using aluminum and zinc electrodes.

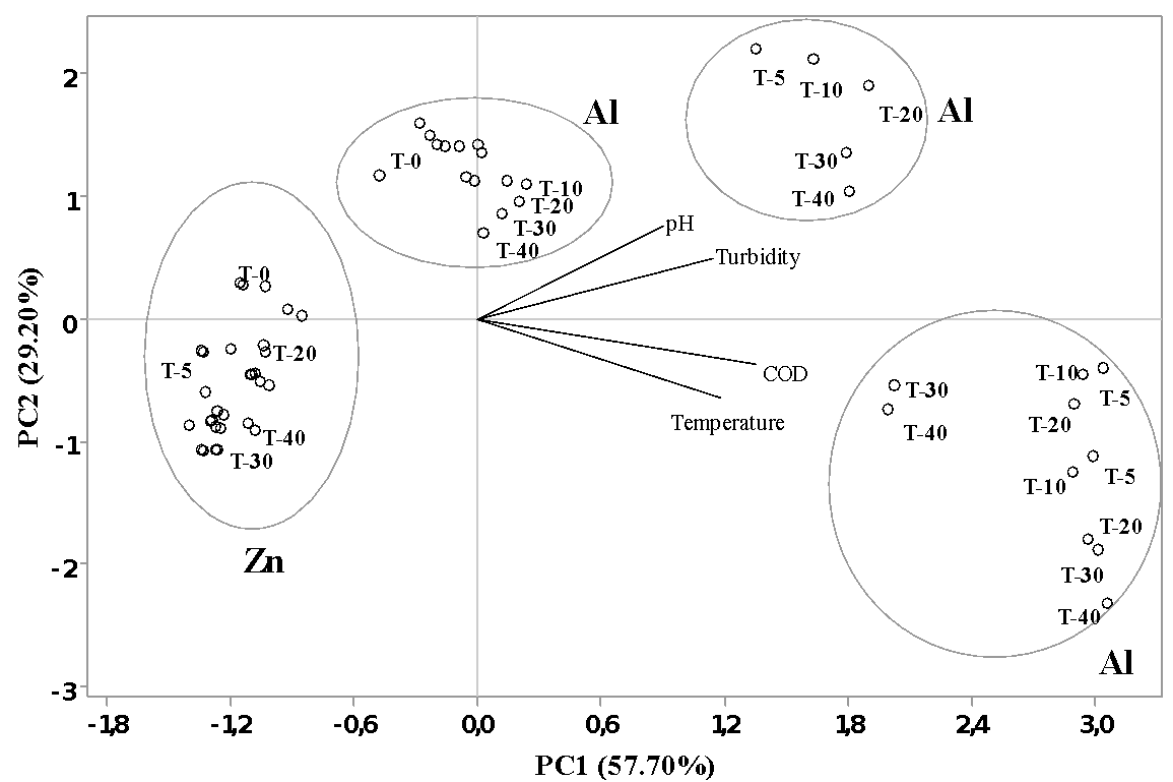

Figure 4. Principal component analysis (PCA) for treatment times and parameters evaluated during the electroflocculation process using aluminum and zinc electrodes. T-0 (zero); T-5 (five minutes); T-10 (ten minutes); T20 (twenty minutes); T-30 (thirty minutes) and T-40 (forty minutes). Al (aluminum electrode); $\mathrm{Zn}$ (zinc electrode).

Figure 4 shows that treatment durations of 20, 30, and 40 min increased correlation among the variable's $\mathrm{pH}$, turbidity, $\mathrm{COD}$, and temperature for aluminum electrode during electroflocculation. For the zinc electrode, there was no positive correlation with any of the evaluated parameters. The experimental data obtained was smaller than the aluminum electrode's data; thus, there was a lower $\mathrm{pH}$ range, turbidity, COD, and temperature. Table 1 shows the correlation coefficients of the first two principal components for the evaluated parameters.

From Table 1, it can be seen that the two principal components (PCs 1-2) were sufficient to describe the model, and together they account for $86.90 \%$ of the cumulative variance. Most information regarding the system ( $86.90 \%$ of the variation) was revealed by CP1 $(57.70 \%)$ and CP2 (29.20\%). Values highlighted in bold were considered significant in the mathematical model, where temperature and COD were the dominant variables in $\mathrm{CP} 1$ and temperature and $\mathrm{pH}$ in $\mathrm{CP} 2$. 
Table 1. Loadings of the variables for the first two principal components.

\begin{tabular}{lll}
\hline Variables & PC1 & PC2 \\
\hline Temperature & $\mathbf{0 . 5 0 8 8 5 0}$ & $\mathbf{- 0 . 5 4 2 7 6 1}$ \\
Turbidity & 0.495557 & 0.420871 \\
pH & 0.391010 & $\mathbf{0 . 6 5 2 4 3 6}$ \\
COD & $\mathbf{0 . 5 8 5 3 2 5}$ & -0.320320 \\
Eigenvalues & 2.3080 & 1.1699 \\
Total variance $(\%)$ & 57.70 & 29.20 \\
Cumulative variance $(\%)$ & 57.70 & 86.90 \\
\hline
\end{tabular}

*Bold values indicate significant correlation $(|>0,5|)$. COD (Chemical Oxygen Demand). PC1 (Principal component 1); PC2 (Principal component 2).

\section{CONCLUSIONS}

This study evaluated the electrolysis duration in effluent treatment using the electroflocculation technique, comparing aluminum and zinc electrodes for parameters such as temperature, $\mathrm{pH}$, turbidity, and COD.

The efficiency of the effluent treatment by electroflocculation varied with the duration, the distance between the electrodes, and the type of electrode used; however, it was efficient and viable as it reduced organic and inorganic residues, which was evaluated indirectly by COD. The parameters with the best correlation to the process were turbidity, $\mathrm{COD}$, and $\mathrm{pH}$.

The efficiency of removing pollutants from aluminum and zinc electrodes was best for the shortest distance between plates $(0.5$ and $1 \mathrm{~cm})$ and a 40 min duration of electroflocculation, and presented better values for temperature, turbidity, and COD.

The electrochemical process is more efficient than traditional techniques in removing colloidal particles in suspension, organic matter, and metals, by generating a coagulant inside the reactor ("in situ") and the combined action of microbubbles generated by cathode. Its advantages include versatility, energy efficiency, speed in smaller systems, simplicity of apparatus used, and non-use of chemical and biological reagents for wastewater treatment.

\section{REFERENCES}

ABREU, J. D.; ADAM, C.; COSTA, A. F.; MARIAN, S.; KOSLOWSKI, L. A. D. Tratamento de efluente proveniente de serigrafia via eletrocoagulação. Brazilian Journal of Animal and Environmental Research, v. 2, n. 1, p. 547-556, 2019.

ADAMS, E. A. Intra-urban inequalities in water access among households in Malawi's informal settlements: Toward pro-poor urban water policies in Africa. Environmental Development, v. 26, n. 42, 2018. https://doi.org/10.1016/j.envdev.2018.03.004

APHA; AWWA; WEF. Standard Methods for the Examination of Water and Wastewater. 19. ed. Washington, 1995.

AQUINO NETO, S.; MAGRI, T. C.; DA SILVA, G. M.; DE ANDRADE, A. R. Tratamento de resíduos de corante por eletrofloculação: um experimento para cursos de graduação em química. Química Nova, v. 34, n. 8, p. 1468-1471, 2011.

BANDEIRA, A. A.; ESQUERRE, K. R.; BORGES, R. B. A regulamentação sobre o tratamento e a disposição final de efluentes industriais: avaliação do gerenciamento de efluentes no Polo Industrial de Camaçari - Estado da Bahia. Revista Direito Ambiental e sociedade, p. 121-148, 2018. 
BEHLING, L.; PAVÃO, D. B.; ALVES, A. A. A.; SANTOS, B. L. B.; TONES, A. R. M. Eletrofloculação aplicada no tratamento de efluente lácteo: delineamento experimental e otimização de múltiplas respostas. In: SIMPÓSIO INTERNACIONAL DE QUALIDADE AMBIENTAL, 11., 02-04 out. 2018, Porto Alegre. Anais[...] Porto Alegre: ABES, 2019. p. 3-13.

BITTENCOURT, L. A.; LIMA, A. A.; SCHLINDWEIN, C.; BANCZEK, E. P.; FURSTENBERGER, C. B. Tratamento do efluente do biodiesel utilizando a técnica de eletrofloculação com diferentes eletrodos. Brazilian Journal of Animal and Environmental Research, v. 1, n. 1, p. 253-266, 2018.

BRASIL. Presidência da República. Lei n. 9.433, de 9 de janeiro de 1997. Institui a Política Nacional de Recursos Hídricos, cria o Sistema Nacional de Gerenciamento de Recursos Hídricos, regulamenta o inciso XIX do art. 21 da Constituição Federal, e altera o art. $1^{\circ}$ da Lei $\mathrm{n}^{\circ}$ 8.001, de 13 de março de 1990, que modificou a Lei $\mathrm{n}^{\circ} 7.990$, de 28 de dezembro de 1989. Diário Oficial [da] União: seção 1, Brasília, DF, 09 jan. 1997.

CANDITO, L. C.; GOMES, J. A. C. P.; JAMBO, H. C. M. Desenvolvimento de reator eletroquímico para a oxidação de compostos de amônia em águas residuais de refinarias de petróleo. In: PAINEL PEMM, 2012, Rio de Janeiro. Trabalhos[...] Rio de Janeiro: UFRJ, 2012.

CERQUEIRA, A. A. Aplicação da técnica de eletrofloculação no tratamento de efluentes têxteis. 2006. 111f. Dissertação (Mestrado) - Universidade do Estado do Rio de Janeiro, Rio de Janeiro, 2006.

CRESPILHO, F. N.; REZENDE, M. O. O. Eletroflotação: princípios e aplicações. São Carlos: Rima, 2004. 96 p.

FERREIRA, M. M. C.; ANTUNES, A. M.; MELGO, M. S.; VOLPE, P. L. O. Quimiometria I: calibração multivariada, um tutorial. Química Nova, v. 22, p. 724-731, 1999.

HAJI GHOLIZADEH, M.; MELESSE, A. M. Assortment and spatiotemporal analysis of surface water quality using cluster and discriminant analyses. Catena, v. 151, p. 247-258, 2017. https://doi.org/10.1016/j.catena.2016.12.018

HASWELL, S., J.; WALMSLEY, A. D. Multivariate data visualization methods based on multi-elemental analysis of wines and coffees using total reflection X-ray fluorescence analysis. Journal of Analytical Atomic Spectrometry, v. 13, p. 131-134, 1998. https://doi.org/10.1039/A705317G

HIGGINS, V.; HOOSHMAND, S.; ADELI, K. Principal component and correlation analysis of biochemical and endocrine markers in healthy pediatric population (CALIPAPER), $\begin{array}{llllll}\text { Clinical Biochemistry, } & \text { v. } & 66, & \text { p. } & \text { 29-36, }\end{array}$ https://doi.org/10.1016/j.clinbiochem.2019.02.004

ILHAN, F.; KURT, U.; APAYDIN, O.; GONULLU, M. T. Treatment of leachate by electrocoagulation using aluminum and iron electrodes. Journal of Hazardous Materials, v. 154, p. 381-389, 2008. https://doi.org/10.1016/j.jhazmat.2007.10.035

KARKI, V.; AGARWAL, R.; ALAMELU, D. Determination of spatial distribution of alloying and impurity elements in zircaloy using imaging secondary ion mass spectrometry and principal component analysis, Vacuum, v. 136, p. 1-9, 2017. https://doi.org/10.1016/j.vacuum.2016.11.015 
KYSAS, G. Z.; MATIS, K. A. Electroflotation process: A review. Journal of Molecular Liquids, v. 220, p.657-664, 2016. http://dx.doi.org/10.1016/j.molliq.2016.04.128

KOBYA, M.; CAN, O. T.; BAYRAMOGLU, M., Treatment of textile wastewater by electrocoagulation using iron and aluminum electrodes, Journal of Hazardous Materials, B100, p. 163-178, 2003. http://dx.doi.org/10.1016/S0304-3894(03)00102-X

MARQUES, M. B. L. Construção de jardim filtrante (wetlands) como alternativa de tratamento de água cinza em uma propriedade rural do município de Ilha Solteira - SP. 2017. 56f. Trabalho de Conclusão de Curso (Graduação em Ciências Biológicas) Universidade Estadual Paulista, Ilha Solteira, São Paulo. 2017.

MOHTASHAMI, R.; SHANG, J. Q. Treatment of automotive paint wastewater in continuousflow electroflotation reactor. Journal of Cleaner Production, v. 218, p. 335-346, 2019. https://doi.org/10.1016/j.jclepro.2019.01.326

SENA M. M.; POPPI, R. J.; FRIGHETTO, R. T. S.; VALARINI, P. J. Avaliação do uso de métodos quimiométricos em análise de solos. Quimica Nova, v. 23, p. 547-556, 2000.

SILVA, P. C. F. Tratamento de Resíduos Líquidos Industriais pelo Processo Eletrolítico: Uma Alternativa para Gerenciamento dos Resíduos Líquidos Gerados nas Indústrias Mecânicas Fabricantes de Equipamentos para Produção de Petróleo. 2005. 96f. Dissertação (Mestrado) - Universidade Federal Fluminense, Niterói, 2005.

SILVA, J. S.; SILVA NETO, A. C. Tratamento da água do petróleo por eletrocoagulação/eletrofloculação. Revista Ambientale, v. 2, p. 104-116, 2010.

STRATE, J. Otimização de um sistema de eletrofloculação em fluxo contínuo para o tratamento de efluentes líquidos das indústrias de laticínios. 2014. 83f. Trabalho de Conclusão de Curso (Graduação) - Centro Universitário Univates, Lajeado, 2014.

SOUSA, D. G.; MARQUES, D. S.; SANTOS, V. S.; SOUSA, A. C.; FIGUEIREDO, G. A. Aplicação da técnica de análise exploratória no monitoramento da qualidade do rio Cuiá, João Pessoa-PB. Ambiência, v. 15, p. 131-145, 2019.

VIEIRA, S. P.; CAVALCANTI, A. P. Obtenção de novos materiais a partir as águas residuais da produção de biodiesel tratadas por eletrofloculação. Revista CIATEC-UFP, v. 9, n. 2, p. 28-36, 2017. 